\title{
A VAST TABLEAU OF MIGRATIONS: CONCLUSION
}

\section{Olivier Forcade}

Sorbonne Université

Rainer Hudemann

http://orcid.org/0000-0002-7199-6808

Emeritus professor

Sorbonne Université, Saarland University

This work is the first result of international research conducted on migrations throughout the world, the initiative and idea going back to Paweł Sękowski of the Jagiellonian University and expanded to a network of young researchers who have come out of Polish universities. Thus, these contributions represent a "work in progress," research which is in the process of being developed in greater depth, in different stages of advancement. Each author has summarised his or her contribution in a concise manner. In the format of the given studies, the epistemological issues raised by the questions addressed and the historiographical issues can only constitute a background, with so much of the field animated by dynamic international debates. An important consideration was that the readings offered in this part of the review did not try to be primarily about these issues of historians' writing. The intermediate published results, often very dense, are all the more useful.

We will try to sketch some of the cross-cutting contributions and the perspectives which their work opens up.

\section{A WIDE RANGE OF THEMATICS}

By way of examples, the contributions attest to the vast range of subjects across the world and currently represented in the work of young Polish researchers. ${ }^{1}$ Beyond their specific content, some of them also facilitate access to research in multiple lan-

1 For instance, the group's first colloquium, referred to in the Introduction, covered equally Catalonia (Blanka Rzewuska), the Palestinians (Elżbeta Deja), the Irish diaspora in the United States (Małgorzata Furgacz), Tibet and the Tuareg (Oleg Kwiatkowska), as well as methods in social psychology (Magdalena Skrodzka).

Addresses for correspondence: rainer.hudemann@sorbonne-université.fr; hudemann@mx.unisaarland.de 
guages - the majority of which are little known save by readers from Eastern Europe - such as that of Krzysztof Popek on the migrations in the Balkans in the $19^{\text {th }}$ and early $20^{\text {th }}$ centuries. $^{2}$

\section{THE WEALTH OF THE ARCHIVES}

The wealth of the archives, Polish or concerning history whether Polish or of migrations across the world, is reflected in this book in order to grasp a wide range of problems. The contributions thus showcase archives which are often little known, notably Polish, French, British, Canadian and North American ones. The Sikorski Archives of the Polish Government-in-exile from 1939 onwards, kept in London, support the arguments proposed in several contributions. On the international level, the Polish archives of the International Commission for Supervision and Control in Vietnam from 1954-1955, in which Poland represented the Soviet bloc, are most instructive (Jarema Slowiak). Several authors highlight the contribution and limits of oral testimony, written or on video and preserved in archives or collected by themselves, for example regarding the reception of Polish refugees in Lebanon and in East Africa during the Second World War (Mikołaj Murkociński) or that of African Americans of the Great Migration from south to north in the United States (Patryk Mamczur).

\section{AN INTERDISCIPLINARY APPROACH}

The book reflects the interdisciplinary approach which is at the heart of the young researchers' project. As a philosopher and lawyer rooted in international law, Aleksandra Samonek analyses the developments and circumstances - notably the declaration of a state of emergency - under which the restriction of human rights, in this case the right to privacy of foreigners and notably migrants, can surreptitiously lead to restricting the rights of citizens in general and thus to undermining democracies. The contribution of Paulina Szydłowska, a psychologist, reflects the complementarity of her discipline with that of historians. Krzysztof Popek, historian and Slavist, dominates the vast research of the Eastern European countries. P. Mamczur combines training as a musicologist and Americanist with that of a historian, featuring the testimonies of American migrants, and Karolina Olszowska as a historian and

2 Cf. G. Hryciuk, W. Sienkiewicz, M. Ruchniewicz, B. Szaynok, A. Żbikowski, Wysiedlenia, wypędzenia i ucieczki 1939-1959. Atlas ziem Polski. Polacy, Żydzi, Niemcy, Ukraincy, Warszawa 2008 (German translation: Bonn 2012); Enzyklopädie Migration in Europa. Vom 17. Jahrhundert bis zur Gegenwart, eds. K. J. B ade, P. C. Emmert, L. Lucassen, J. Oltmer, Jochen, 2. Aufl., PaderbornMünchen 2008. 
Turkologist analyses refugees in Turkey. J. Slowiak who devotes herself to internal Vietnamese migrations is also an Americanist.

The cascade of disasters which were the consequence of the National-Socialist policy across the world are evident in this book in a very large range of consequences.

\section{INTERNATIONAL ORGANISATIONS: FIELD AND LIMITS OF ACTION}

International organisations take on a decisive role in a majority of the great migrations of the $20^{\text {th }}$ and $21^{\text {st }}$ centuries - such as the International Refugee Organisation (IRO), the United Nations Relief and Rehabilitation Administration (UNRRA), or the American Polish War Relief (APWR). The scope and limits of their actions are explicitly highlighted in all their great diversity. Their intervention was, for example, indispensable for those who wanted to reach the United States or Canada. It was similar for the Polish children reunited in Barcelona (P. Sękowski). The ambivalence of this role emerges in M. Murkociński's contribution, notably in the problem of the repatriation of Displaced Persons to a Poland henceforth under communist government: while the principle of internment of refugees in East Africa facilitated a forced repatriation, their immersion in society in Lebanon favored a refusal of such a repatriation. This was all the more so as Lebanon, independent since 1943, refused until 1956 to recognize the communist regime in Warsaw, whereas in Africa the decision fell to the British authorities which had recognized it in 1945. The IRO was in a particularly difficult position regarding the protection of refugees in Turkey which didn't officially recognize it (K. Olszowska). The documents of the Polish members of the International Commission for Supervision and Control in Vietnam, preserved in Warsaw and made use of by J. Slowiak, allow us to follow in detail the mechanisms of the manipulations of international commissions by the interested parties - in this case especially by the Democratic Republic of Vietnam - and the opportunities and limits of their actions.

\section{VARIETIES OF MIGRATIONS AND RECEPTION IN HOST COUNTRIES}

The types of migrations analysed sometimes represent a specific type, but for the majority several types are superimposed on each other, get entangled, and follow each other more or less rapidly. In the Balkans, internal and cross-border or transnational migrations become tightly interwoven across the centuries (K. Popek). From a systematic point of view, as migrations that are basically often ethnic or religious, these Balkan migrations are different from other internal migrations. Using retrospective testimonies of African American migrants, P. Mamczur brings out the fundamental elements of the "Great Migration" - initially essentially economic - from the south 
to the north of the United States between 1917 and 1960 and develops a picture of the interweaving of economic, family, and cultural problems and the strategies forged to overcome them. The de facto partition of Vietnam in 1954 gave rise to a massive internal migration from the communist north to the south and a very small migration in the opposite direction, as analysed by J. Sloviak.

The particular problems which elites may encounter are fundamental for a large number of migrations. K. Olszowska thus evokes the anti-Nazi academic and German resistance members' migration to Turkey which actively contributed to the consolidation of the secular state there. Other migrants over the long term supported North American scientific power in technology as much as in social sciences - notably sociology, history, political science -, in art and cinematography. The survivors of the millions of prisoners of war and labourers forced into the service of the German war economy were at the end of the war transformed into Displaced Persons and so into refugees or migrants. Their repatriation to Eastern Europe, often against their will, was carried out in the American and British zones in occupied Germany but halted relatively quickly in the French zone.

The forms, scales and stages of the reception and integration of refugees and migrants in host societies stand out particularly clearly in several contributions. Thus, in Great Britain after 1945, the difficult situation regarding the hosting of refugees contributes to transforming this experience of the former soldiers of the Anders' Army into a step migration to the United States and Canada (K. Kartasiński). A number of Polish refugees who had arrived, via Iran, to live relatively freely in Lebanon or to be interned in East Africa before moving on elsewhere know this type of migration in even more numerous steps (M. Murkociński).

The book pays particular attention to children, often left on the margins of large studies. P. Sękowski analyses the forgotten example of children found in Austria and reunited in Barcelona: one hundred children, mostly from the western provinces that had been German before the re-establishment of the Poland state in 1918 and from the Lódź region that before the First World War had been a part of the "Kingdom of Poland" within the Russian empire - these territories having been annexed by Germany in 1939. Some of the children had German fathers as victims of the SS policy of Lebensborn which forced women deemed of "Germanic" race in the occupied territories into relations with members of the SS with a view to procreating future soldiers. In her analysis of cases, P. Szydłowska, similarly directs attention ass a psychologist to the children, who remain relatively little integrated in these analyses to the present day.

\section{THE COLD WAR}

The London-Warsaw duality of the Polish governments during the war and the post-war period and more generally the tensions generated by the Cold War run through a large number of the contributions. The problem relates particularly to the 
complexity of problems arising from the recognition of the communist government in Warsaw by the Allies, to the detriment of the Polish Government-in-exile since 1939 whose means of action to benefit refugees declined rapidly after 1945, even if it officially existed until 1990 (K. Olszowska, K. Kartasiński). The opposite situation: the non-recognition of the Warsaw government which had come under communist domination in 1945 could facilitate protection but also further increase the complications. Thus Spain, which didn't recognize the Warsaw government until 1968 (the Vatican in 1972), as well as Lebanon, independent since 1943, "provided relatively much more protection to surviving Poles", as shown by P. Sękowski for the Polish children in Barcelona, and by M. Murkociński comparing the very different situations of Polish refugees in the British colonies in East Africa and in Lebanon.

\section{STATISTICS AND METHODS}

The difficulty posed by migration statistics and their interdependence with methods of analysis is an issue that cuts across many of the contributions. K. Popek thus develops our statistical knowledge and its limitations regarding the multiplicity of movements - above all Muslim - in the Balkans in the $19^{\text {th }}$ century, in order to then structure these according to the great variety of motivations and political, economic, social and institutional situations, and by showing the scales of interactions between these movements. From the point of view of qualitative methods, the contributions represent a multitude of very different cases and demonstrate that it is right, depending on the respective situation, to integrate political, institutional, social, economic, cultural, religious, artistic and literary analyses, including music. Starting with the example of Polish veterans in Canada and in the United States (K. Kartasiński), these articles equally reflect the limitations of oral history effected at a remove from the individual and collective experience of actors, sometimes after several decades, as well as the possibility that it might nevertheless have a bearing on subsequent, methodologically more targeted research, of which this volume gives a first glimpse.

In the conception of this volume, certain articles complete each other. Thus, for the belated recollections of emigrés in America (K. Kartasiński), certain explanations can be found in the differences in institutional, political and social structures in very different situations, such as those analyzed by M. Murkociński, choosing examples pertinent to East Africa and Lebanon. P. Szydłowska shares the essentially quantitative results of recent international research in psychology, regarding the strategies of integration, adaptation, assimilation and acculturation observed in the migrants' behaviours and in their host societies. In conclusion, based on a dozen recent interviews with Polish children educated in Madrid, she pleads for an expansion of psychological methods towards qualitative work, which frequently arrives at different results. Notably, this would allow the formulation of hypotheses regarding numerous additional factors, cultural and political as well as social or economic, on 
an individual or family level, which are in reality largely neglected by current psychological research even though they are indispensable in the analysis of these migration situations. This evolution could enable a deepening of the dialogue between psychology and the other disciplines represented in this book.

Translation: Dr. Andrea Caspari-Hersh, Princeton/Mass. 